\title{
AIR PRESSURE: Temporal Hierarchies in Nepali Aviation
}

\section{TINA HARRIS \\ University of Amsterdam}

(D) https: / / orcid.org/0000-0003-0357-2074

It was 07:52 Zulu on the digital clock in the air traffic control tower. In aviation-speak, this means it was 1:37 p.m. in Nepal, peak time for air traffic at Tribhuvan International Airport in Kathmandu (KTM). I stood quietly at a distance behind the controllers with a glass of strong black coffee, marveling at the activity on the single runway of Nepal's only international airport. Tibet Airlines was about to push back. Biman Bangladesh Airlines was next in line, then Singapore-based Silk Air, followed by Malindo Air from Malaysia. An Air India aircraft arrived, followed by the Bhutanese Druk Air, then a series of five small domestic Yeti Airlines and Buddha Air turboprops, all in a row. Massive planes landed, tiny ones took off, and helicopters hovered and circled in the near distance. The four or five main air traffic controllers were hard at work, with occasional bursts of joking and laughing. One controller was tapping frantically at a digital display. I snuck a quick glance from a distance: there were at least seven bright dots clustered around Pokhara, the second-largest city in Nepal. It turned out that another airport southwest of Kathmandu had closed due to severe weather. All the aircraft on the display were holding, circling, waiting to land. In the Kathmandu tower, a wave of concern mixed with mirth; we watched a Buddha Air turboprop head back to the parking bay after waiting for thirty minutes to depart. More aircraft 
were gathering and holding above KTM, with some waiting to land for at least half an hour. "Welcome to our reality," one of the controllers said with a grin.

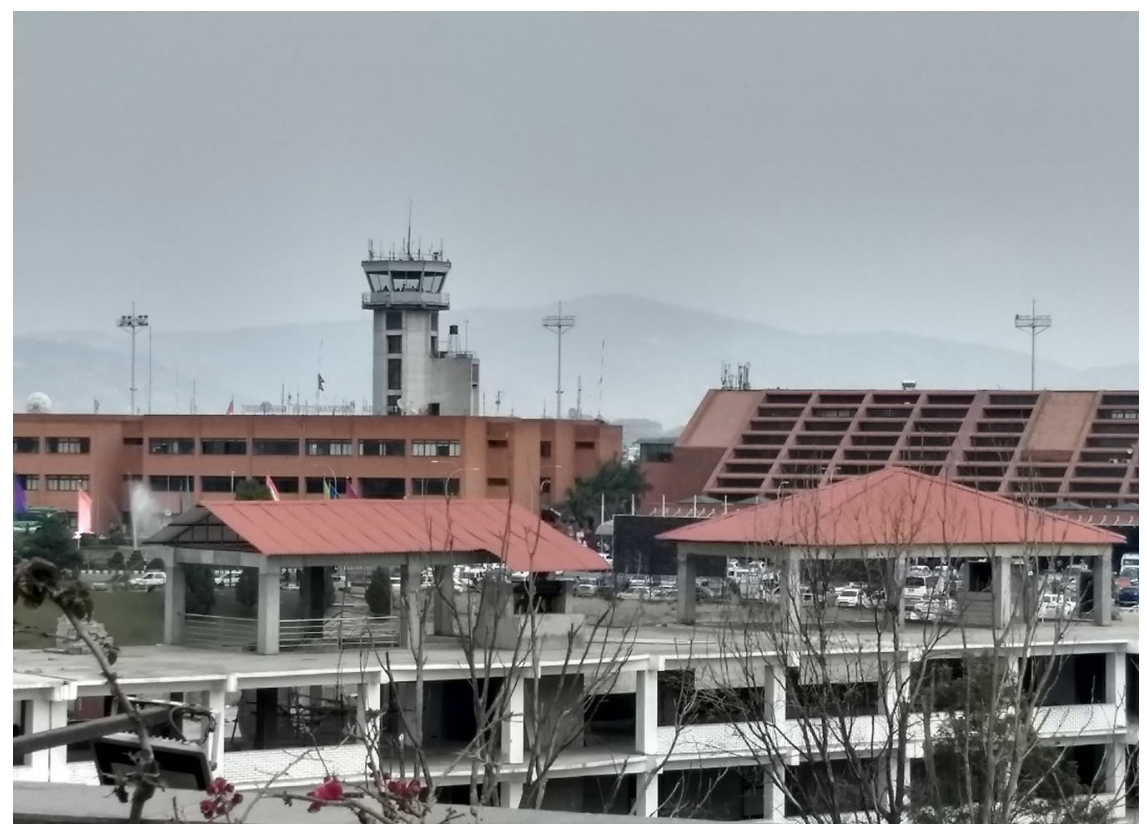

Figure 1. Tribhuvan International Airport, Kathmandu. Photo by Tina Harris.

The skies are becoming more crowded. Those who work in the global aviation industry are wondering how to cope with staggering future growth predictions: world passenger traffic exceeded four billion passengers in 2017, and this number is expected to double in the coming twenty years (IATA 2018; ICAO 2018). International aviation organizations such as the International Air Transportation Association (IATA) state that significant increases in mobility across borders and competition between new low-cost airline companies create major capacity issues in the industry, as well as increased delays. While the highest percentage of global passengers used to hail from the United States and Europe, airlines from Asia have recently been carrying the most passengers: this includes young Nepali men from low-income villages who migrate to Qatar to build stadiums for the 2022 World Cup and middle-class Chinese women flying to Amsterdam on guided tours. At the same time, increasing carbon and other emissions from the aviation industry make for serious threats to the future of the earth. ${ }^{1}$

Yet a disjuncture exists between the increase in air connectivity and the capacity of the aviation sector to stay on top of the growing congestion in the skies 
and at the airports. In Nepal, air traffic controllers, operations managers, pilots, and crew find themselves under considerable pressure to deal with the steadily increasing flow of passengers. While these drivers of increased air traffic, as well as the uneven consequences of congestion, are familiar characteristics of the speedup of capital more generally, they have been exacerbated by demands specific to the region: a significant increase in low-cost carriers and routes in a highly competitive Asian and Gulf market since 1992, a growth in tourists after the 2015 earthquake, and increased numbers of labor migrants flying out of Nepali villages to work in the Gulf States, Malaysia, and India. Poor road infrastructure and landslides have also made it easier, faster, and even cheaper for some to travel by airplane from rural Nepal to Dubai than to do so by road within the country.

The increase in air traffic necessitates not only more space but also more time to fit the hundreds of aircraft in the air and on the ground. Consider this example: during the peak trekking season in late spring, an air traffic controller working in a tower at the gateway to a mountainous trekking destination in Nepal needs to clear ever more landings and takeoffs within the small window of time in the morning when the skies are blue and clear, since no-frills turboprop VFR landings (landing by sight or "visual reference," instead of using instruments) in volatile weather are the norm in many remote areas. As the erratic mountain clouds roll in and delays are imminent, the controllers must face irate passengers - some of them VIPs such as high-level politicians who insist on preferential treatmentas well as some airline and helicopter companies that look for steady returns on profit to keep up with the growth in air services.

These hallmarks of capitalist globalization - increased connectivity, the collapse of time and distance, and the general feeling that life is speeding up — shape the premise of David Harvey's work on time-space compression and much of the literature on (aero)mobilities (Harvey 1989, 232; Sheller and Urry 2006; Cwerner, Kesselring, and Urry 2009; Adey 2010). Indeed, glossy advertisements for a seamless connection between New York and Dubai in record time in a first-class suite on Emirates Airlines are now fairly common. But they stand in sharp contrast to the everyday practicalities of aviation in Nepal. The tensions between the technological advancement of "global aviation" and the current context in the country means that aviation discourses focusing on the global South are often characterized by the language of "lagging behind" or needing to "catch up" with the rest of the world. Much of this is about adhering to (and shaping) socially constituted markers of time such as departure times, sunrise and sunset, or ideas of the past, present, and future, with the knowledge that multiple understandings and experiences of 
time - temporalities - overlap and are in tension with one another (Adam 1998; Frederiksen and Dalsgård 2014). Aviation personnel in Nepal are not simply stuck with the choice of either speeding up or getting left behind. Instead, they adjust their lives and everyday practices to fit into the "temporal expectations demanded by various institutions, social relationships, and labor arrangements" (Sharma 2016, 133; emphasis added). In doing so, they highlight and expose severe inequalities in global aviation infrastructure, while also contributing to them in ways that reveal specific ideas of the future of the state.

In this article, I examine how the need to fit more aircraft into the air and on the ground to keep up with the increase in global air traffic produces a kind of air pressure (see Anand 2011) that generates specific experiences and practices in the aviation world. These effects can be roughly divided into two overlapping types. The first set of effects is more immediate. It emerges from the growing gap between the temporal expectations of airline companies, their passengers, aviation regulators and investors, and the everyday practices and experiences of the very people who make the local dimension of infrastructure work-such as air traffic controllers, pilots, crew, and operations staff. Here, I aim to show how temporal regimes (how time is ordered, structured, produced, and subject to power [Hartog 2015]) in aviation overlap with existing spatial and social hierarchies, such as tendencies to privilege international over domestic flights and global aviation over Nepali aviation. The second set of experiences is more specific to the place of the global South within a wider neocolonial world order. While "narratives of progress" (Hetherington 2017) dominate the aviation industry in general, in practice that industry is profoundly striated and uneven. This is accentuated by specific practices in the aviation world of deferring to what is marked as "international" or "global" — whether they are outbound flights or in hiring practices for pilots with futurity. In other words, to be part of the international or global aviation community means to show that you can plan for the year 2050 and beyond, and Nepal and the global South — or indeed, many places that have experienced the unevenness of global capital and its transformation-often find themselves relegated to the backseat of such conversations. The very idea of a global temporal regime, in other words, "the time of the global," is harnessed by aviation personnel and used in multiple ways to address regional or national concerns: to vent frustrations at the unfulfilled promises of the state, or to assert a sort of national resentment at being relegated to the lowest rung of hierarchies in international aviation - "the time of the nation." While the effects of congestion or disruption on local Nepali aviation planners are serious, creating temporal chokepoints (Carse, 
Cons, and Middleton 2018; Cons 2018; Carse et al. 2020) that in turn have massive implications for the wider global system, some kinds of disruption, such as unpredictable weather, can also reconfigure temporal hierarchies, bringing the value of local knowledge of the skies and manual piloting back to the forefront of the global discourse on aviation futures. A closer look at the effects of air pressure - where the temporal articulations between global aviation and local lives matter just as much as the disjunctures — can lead us to a better understanding of how global temporal regimes can shape lives. ${ }^{2}$

Although aviation turned out to be a significant departure from my previous long-term fieldwork on cross-border trade in the Himalayas, I was drawn to it partly because of similar socioeconomic changes wrought by new infrastructural connections in the region. I wondered what a more volumetric approach could reveal_-looking at processes of economic change, but in the air (Elden 2013; Billé 2018). Since 2009, some in Asia have experienced a clear increase in air-enabled mobility: congested airports and delays, the proliferation of low-cost carriers, or the strategy by the Chinese Civil Aviation Authority of an "Air Silk Road" linked to the wider Belt and Road Initiative (Lin and Ai 2020).

I conducted the fieldwork for this project in several bursts in 2012, 2016, and 2018 instead of during one extended period, perhaps not uncommon for an anthropologist readjusting to the temporal expectations of academic life after having children. I spent much of this work in flight attendant training schools, in cafés around airports, in peoples' homes, in airport terminals' landside areas, or at the Civil Aviation Authority office. I spoke with air traffic controllers, helicopter pilots, jet pilots, journalists who focus on aviation, flight attendants, trainers, operations managers, airport managers, airline executives, and engineers - for both domestic and international carriers. Part of the research involved travel on small turboprop airlines to smaller airports in mountainous areas, where I spent time in airport terminals, spoke with local politicians, and conducted brief observations in air traffic control towers.

What became clear throughout this research was aviation workers' frustrations with balancing different expectations linked to maintaining the tempo and pace of an infrastructure premised on the idea of constant flow. This included pressures to give aircraft takeoff clearance before cloudy mountain weather rolled in, having to temporarily shut airports and local roads due to politicians traveling during "VIP movements," and not being able to adhere to the promises of future airport expansion projects that would accommodate passenger overflow. In Extrastatecraft, Keller Easterling (2014) shows how organizations such as the 
International Organization for Standardization (ISO) — which strives to develop internationally consistent rules for quality — rationalize idealistic narratives of infrastructure space overall by strengthening the power of the state and obfuscating economic inequalities and complex political realities. The aviation industry also produces idealistic stories of infrastructural space as a whole, but here I will draw attention to how global temporal regimes work in this manner. Planning for the future in international aviation means that you plan for a particular kind of future, one that is flattened out and often geared toward the most privileged airline companies, technologically advanced airports, and elite travelers. In the sections that follow, I show how unpicking some of these intricate "tangles of temporalities" can point to unexpected and surprising futures.

\section{ON-TIME PERFORMANCES: Institutions and Infrastructure}

The institutional landscape of aviation is made up of layers of regulatory bodies that structure policy development and maintain standards at the international, national, and airport scales. The trade organization that represents airline companies, IATA, and ICAO, a specialized agency of the United Nations (UN) and regulatory body that oversees global aviation standards, are two of the largest organizations in global aviation that represent industry interests. In addition, most nations have their own civil aviation authorities, responsible for regulating aviation safety and efficiency standards at the state level. In Nepal, the Civil Aviation Authority of Nepal (CAAN) is overseen by the government's Ministry of Culture, Tourism, and Civil Aviation. The Nepali organization is somewhat unique in its uncomfortable position as both a service provider and a regulator: it serves not only the interests of airline companies but also regulates safety. Both ICAO and local media have sharply criticized this dual, often contradictory role; as of 2017, legislation is in place to separate these two functions at some point in the near future.

The long-range institutional structuring of infrastructure space is, as Easterling $(2014,133)$ has claimed, "not a master plan but a set of counterbalancing interdependencies." Similarly, the institutional structuring of aviation in Nepal comprises a set of interconnected variables on multiple national and international scales, where not just the spaces but also the timeframes that institutions direct play a prominent role in shaping local aviation landscapes. While Nepal has had an aviation industry since the 1950s, the national carrier, Nepal Airlines (formerly Royal Nepal Airlines), had a monopoly on international flights to and from Nepal in the 1970s and 1980s, with direct flights to international stops such as Frankfurt, Shanghai, London, and Dubai. But following the restoration of multiparty 
democracy in 1990 after fifty years of absolute monarchy, which led Nepal into reform with sweeping economic policies, the inauguration of a liberal-skies policy in the country led to a dramatic shift in the aviation sector in 1992 (Thapa 2019). Nepal had long been seen as lagging behind U.S. aviation deregulation in the 1970s in the broader context of global shifts toward competition and marketization. Open skies (the opening of the aviation market to privatized airline companies) meant that Nepal Airlines, still the sole national flag carrier, began to encounter increasing competition from several brand-new domestic airlines, such as Shree Airlines, Yeti Airlines, and Buddha Air. Since then, the number of airports in Nepal has increased tremendously, from a handful in the late 1980s to about fifty-five (of which thirty-three are operational) in 2019, not to mention the fifteen domestic and nearly thirty international carriers that now fly in and out of KTM for twenty-one hours a day. The problem with this growth, according to some CAAN representatives, is that the facilities that make up this infrastructure (for example, airport buildings, landing system technology, and some of the aircraft) have remained virtually unchanged since the $1990 \mathrm{~s}$, while congestion has increased (CAAN 2017, 35). The congestion stems especially from Tribhuvan International Airport in Kathmandu (KTM), the only international airport in the country, with

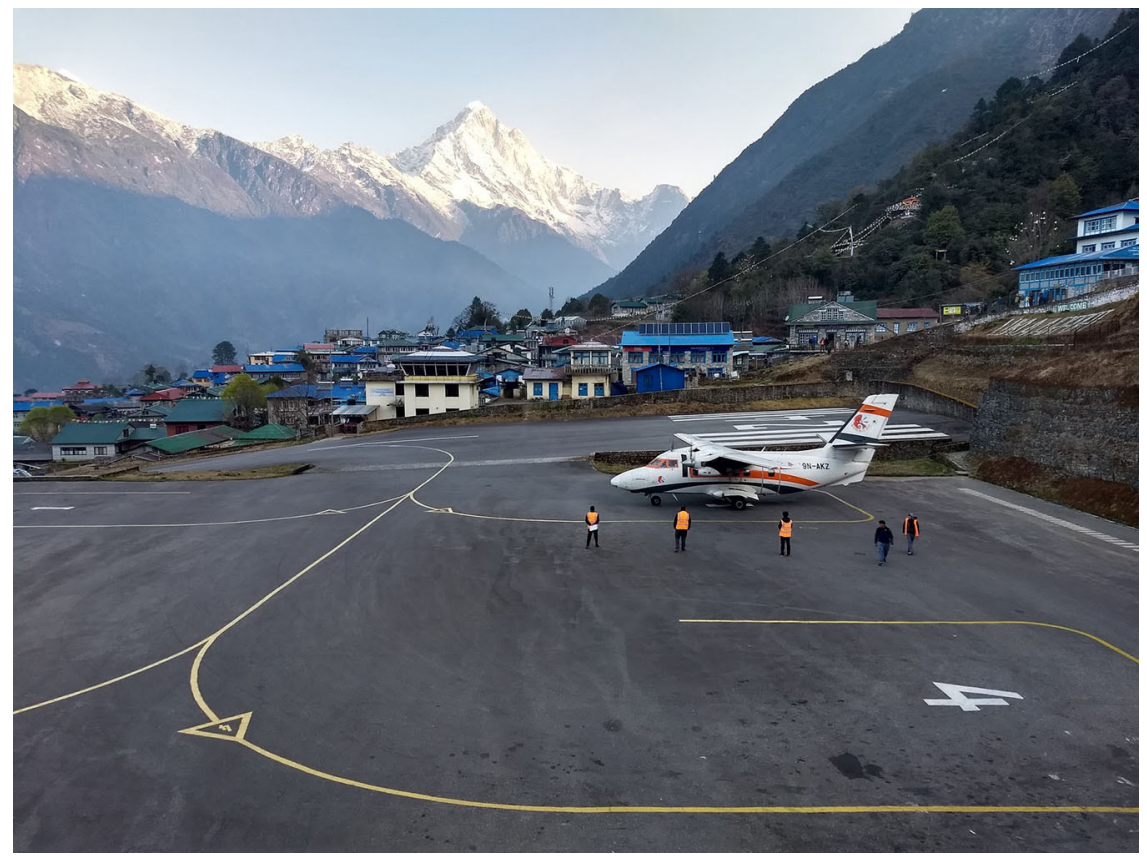

Figure 2. Tenzing Hillary Airport in Lukla, one of the many domestic airports in Nepal. Photo by Tina Harris. 
a single runway that accommodates both arriving and departing international and domestic flights (Golf 2017).

The constraints are immense. At KTM, there are only nine parking bays for the hundreds of international and domestic airlines that fly in and out of Kathmandu every day. A former regional ICAO director has not shied away from admitting that every night after KTM closes its flight operations, a shovel team heads out to patch up surface issues and holes on the runway (CAAN 2018, 3). ${ }^{3}$ Operations managers in all airspace sectors must also deal with the narrow Nepal Flight Information Region (FIR), or more commonly, how airspace is divided by country or region, where Indian army jets appear as soon as a Nepali aircraft even brushes a wingtip over the militarized border with India. A massive gap in communication technology exists between KTM and remote airports that can only use basic equipment to land planes, often with a single air traffic controller or assistant. In addition, getting to many of Nepal's rural airports involves flying over high mountains with unpredictable weather and cloud cover.

One of the engineers for a domestic airline, after discussing all of these constraints, said to me with a sigh: "Sorry to say, but this is the real scenario. The governmental sector won't update these problems unless something [bad] happens." And unfortunately, bad things do happen. In the middle of my fieldwork period, a US-Bangla Airlines aircraft from Dhaka crashed on the side of the runway at KTM, killing fifty-one people, leaving twenty survivors. The reported cause of the crash was a disorientated, upset pilot and/or miscommunication with an air traffic controller. The reality is that Nepal remains one of the most dangerous places in the world for air travel. But whenever I asked aviation workers what they wanted me to tell my readers about aviation in Nepal, almost all responded that "flying in Nepal is not dangerous." Engineers, cabin crew, operations staff, and air traffic controllers all asked me to "put in my book" the "real scenario" of highly skilled Nepali cabin crew, pilots, and air traffic controllers forced to work within the limitations of poor infrastructure, a single congested international airport, the terrain and weather, an increase in carriers and routes, a shortage of aviation workers, distrust of political parties, and pressure from airline management and VIPs. One of the challenges in writing about aviation in Nepal is not to contribute to the pervasive discourse around sloppy aviators from the global South, while acknowledging the fact that safety standards still need tremendous work. We also need to understand better how these standards work, despite multiple constraints. Safety in Nepal indeed makes for a serious matter of concern compared to other international airports' assumed neutral standards, and Nepali aviation is therefore seen 
as either in need of education, development, or - given that all of its airlines remain banned on the EU Air Safety List_-something to be avoided altogether until things improve. Perceptions of lag or backwardness are, in fact, codified in policy.

One example is ICAO's "No Country Left Behind" initiative, implemented in 2014 and meant to provide support for states to "harmonize" global standards and recommended practices in aviation through capacity building and training, particularly for countries with significant accident records like Nepal. A number of these trainings focus on communication between pilots and controllers, always conducted in what is called Standard Aviation English. "English: The Language of the Skies" is the motto of the ICAEA, the International Civil Aviation English Association, which develops workshops and tools, once again, to "harmonize" the use of standard aviation phraseology across the globe, particularly among the air traffic controllers and pilots whose first language is not English. Expert discourses often attribute accidents to poor English proficiency rather than factors such as inadequate training or other forms of miscommunication (Estival, Farris, and Molesworth 2016; Kim 2018). These discourses of standardization can prove paternalizing. Global standards, as Andrea Ballestero (2019, 33) has shown, concern the continuity of ideals, "suspicious and magical at once," smoothing out relations between local variables. Aviation standards work similarly for time: with no country left behind, those in the aviation world are obliged to head in the same direction, toward the same future, at the same speed - the speed of global industrialized capital.

\section{TEMPORAL EXPECTATIONS: International over Domestic}

"In today's fast-paced world, efficiency is the key to success," reads the first page of a feature on the NextGen aviation system, the latest in digital advancement for maintaining on-time passenger service in airports around the world. Features and advertisements in Air Traffic Management magazine and other aviation industry publications stress a smoothly functioning aviation infrastructure that aims for unfettered mobility paired with economic growth — a rhetoric shared with fantasies of seamless logistics operations (see, for example, Cowen 2014; Guyer 2016; Gambino 2018; Lin 2018). In reality, this kind of functioning is difficult to achieve. Take the holding pattern, for example. Three of the most common reasons for delays in landing are inclement weather, full traffic capacity at an airport, and an incident on the ground. In such cases the controller instructs the pilot to hold the aircraft by making it circle in an oval pattern over a destination in a state of suspension as the pilot waits for clearance to land. In Kathmandu, holding patterns are becoming 
more and more common. The single runway, numbered 02 at one end and 20 on the other (i.e., facing 20 degrees northeast on one end and 200 degrees southwest on the other), for all international and domestic flights leads to severe congestion when there are any delays. Ramesh, a middle-aged senior air traffic controller, explained how he experiences the congestion from the Kathmandu tower:

All arriving aircraft are coming from runway 02, and domestic are departing from runway 02 as well. But most of the international airlines request runway 20 due to the [mountainous] terrain. But departing from runway 20 means that there are no arrivals from runway 02. [Makes circling holding motions with his hands.] These [aircraft] come to a hold over there, a hold over there, a hold over there. To depart one single aircraft, we have to hold five here, five here, and five here. Fifteen aircraft will be held for this departure! If I don't give a departure, this international flight has connecting passengers. This [aircraft] has its own schedule, and their own renowned name on the market because [sarcastically] "[name of international airline] is always on time" [everyone laughs]. So the pilot has to maintain the on-time performance, right? So he always wants to make his departure on his own time, but we are unable [to grant this]. Although we are trying our best, it's getting delayed and delayed and delayed, sometimes a couple of hours.

While there is officially no priority in clearing takeoff and landing other than who is next in the queue at any given time, international flights with connecting passengers clearly constitute the source of some pressure for Ramesh. These "prestigious" flights create pressure to move ahead in time, though for social, not technical reasons. Any delay or grounded aircraft marks a disruption to the efficient machine of international air travel. Ramesh does not want to hold up fifteen other aircraft just to let a single jet depart from runway 20; his main concern is with safely landing planes at KTM. On the other hand, this kind of bottleneck has significant repercussions on the international market. Passengers departing from Kathmandu, including many relatively well-off Western tourists and Asian businesspeople, need to make their connecting flights. The international airline that Ramesh works with wishes to maintain its award-winning on-time performance, and their pilots also often feel the brunt of this pressure. As profit derives from passenger experience, both the Nepali controller and the jet pilot find that others with different temporal expectations - such as the airport authority or the parent airline company — come into conflict with their own control over departure time. 
This pressure to prioritize the international carries traces of the neocolonial, evident in how imperial geopolitics have historically shaped air travel, moving some people more quickly through the air than others, privileging white tourists over local West Indians, for example (Sheller 2010; Bhimull 2017).

While we may think of the world of aviation operations as governed by digital clocks set to synchronized Zulu time and standardized, precise takeoff slots, in practice, the maintenance of air infrastructure is a matter of constant negotiation and improvisation (Peters 2009). Anthropologists and geographers have demonstrated that we should not regard infrastructure as a stable, fixed "thing" out there in the world, but rather as something driven and upheld by people (Simone 2004). Infrastructures have always concerned constant maintenance, and they often fail or crumble (Graham and Thrift 2007; Cowen 2014; Berlant 2016; Anand 2017, 231-32). More recently, researchers have also paid careful attention to the temporality of infrastructures, for instance, how they can stretch beyond human lifetimes (Bowker 2015), or how they can be used to think through other nonhuman scales and time spans (Anand, Gupta, and Appel 2018; Hetherington 2019; Joniak-Lüthi 2019; Cons 2020; Lord, Drew, and Gergan 2020). Less clear is how daily negotiations of time used to maintain the movement of air traffic work in practice. When does time pressure conform to wider societal hierarchies, and when does it work against them? In the scenario described earlier, for example, an international on-time departure produces considerable pressure to curtail the time of national air traffic control. With more people flying, there is less space and time available for aircraft to fit in the sky. The gaps between the expectations of international aviation turnover times and the on-the-ground (or in-the-air) experiences of maintaining Nepali air infrastructure become wider. Since technological or material fixes to the problem of congestion - such as a new runway or radar system - are long-term investments, these immediate, everyday experiences of prioritizing who goes first in the queue reinforces structural hierarchies within the broader aviation sector.

Shrinking time is an issue, especially when paired with volatile but not random weather that bears specific local and seasonal patterns. At one small airport in Nepal, you can look across the runway to the terminal on the other side from the vantage point of the air traffic control tower. Dipak, a young air traffic controller, gestured toward the big window of the terminal. I peered through the binoculars, usually used for Foreign Object Debris (FODs) like stray equipment or wild animals that could interfere with the safety of the runway. The weather was not good, and the incoming flights from KTM were delayed. I could see the pas- 
sengers looking impatient and anxious, and got a shock once I could clearly make out their expressions: they were glaring right at us! Thankfully, I remembered that they could not see individual faces through the darkened glass, but the stares were unmistakable. They were willing the controllers in the tower to do something, to fix their delayed flights. The pressure was so immense, even I could feel it. Dipak gestured again toward the terminal: "See? They can see us. If we go over there they will 'attack' us. Especially if their flights are cancelled." It was only a few hundred meters away, but he said he "never goes over to that side." In the afternoon, the airport ended up closing because of visibility under five kilometers; standardized limits such as these became proxies for making decisions with wider repercussions for the network of flight connections. Two station managers for different domestic airlines came up to the tower after the closure announcement. They were having tea, eating momos (dumplings), and looking out at the clouds, chatting to the controllers about the lack of visibility. Suman, another controller, uttered sarcastically under his breath, "Yeah, you can tell these guys are meteorologists."

With such dynamic, unpredictable weather patterns, everyone who has spent some time in the industry suddenly becomes a climate expert. Activity at this airport happens in bursts that are based on short windows of time, often dependent on the elements - an hour when the sky clears, two hours when the runway at the hub airport is less congested, another half an hour before the airport closes at sunset, since there is no nighttime lighting system. Compare these short windows of time with other airports that are open 24/7 and have night technology or ILS (Instrument Landing System) approach systems that stretch flying time to minimize disruption and allow aircraft to land at any time in nearly all kinds of weather. While excellent work exists in the aeromobilities literature on frictions, congestions, and disruptions (Martin 2011; Lin 2014) — such as during the Eyjafjallajökull volcanic eruption in 2010 — too much emphasis remains on how the hypermodern, technological aspects of aviation systems work mostly in global industrialized societies (see, for example, Budd and Adey 2009; Kitchin and Dodge 2014). The Nepali case shows how global temporal regimes structure time in ways that have profound implications, and productive use, for those already relegated to the bottom of the hierarchy of global aviation. At Suman's rural airport, disruption was the norm, the way that "uninterrupted [electric] power" is actually a surprise in parts of the global South (Gupta 2015, 559). Suman found himself adhering to the temporal expectations of urban and international passengers unused to such regular interruptions in aviation. Pilots that flew trekking tourists to mountain 
airports encountered similar kinds of time pressures, and even abuse from passengers:

Due to many atmospheric pressure changes, temperature changes, we have lots of local weather. Due to that reason, there are lots of delays, lots of cancellations, but the passengers do not understand those problems. And sometimes even passengers try to push us: "Why are you not flying? We've been waiting. Why are you not flying? That [other] aircraft flew fifteen minutes back, or maybe half an hour back, but why are you not flying?" But in half an hour, there are lots of changes, especially in the mountainous areas. When the wind blows from the mountains, the weather changes in five minutes. So maybe that other aircraft was capable to land, but we won't be able to land, because the weather has already changed. Those things are not understood by passengers. And there are even more pressures by the management, the marketing, and that pressure comes to us.

To illustrate, one of the airport operations staff members read out angry TripAdvisor comments: "Terrible airline. The weather looked fine. The other airlines flights were on time. Why didn't we go?" These narratives reveal the pressure to keep the turnaround time at a minimum and to generate profits in a sector where the risk of cancellations and accidents is fairly high. Weather can also be considered part of the local infrastructure, something that the global discourses of standards do not always take into account. Temporal hierarchies of corporate ontime performance often omit the nonhuman, the fluctuating weather or surprise bird strikes. A weather event can turn such a hierarchy on its head, creating both disruption and movement in unexpected ways (Birtchnell and Büscher 2011). For instance, a domestic flight can obtain clearance for takeoff if its flightpath is unaffected by the weather, while the international flight is left behind on the ground by a storm that comes in a few minutes later. These contingencies in aerial space, where aircraft fly through different kinds of weather, stand in stark contrast to Tim Ingold's "weather world," a world predicated on the sameness of the human experience of traveling along a ground conditioned by the air (Ingold 2010).

\section{GEOPOLITICS AND CHRONOPOLITICS: Global Aviation over}

\section{Nepali Aviation}

In Time and the Other, Johannes Fabian (2014) argues for paying closer attention to cultural experiences of temporality, in particular to how and when coeval- 
ness is denied. Because some nations or groups in certain parts of the world are considered more "backward" in time as others move forward, Fabian claims that "geopolitics has its ideological foundations in chronopolitics" (see also Virilio 1986; Fabian 2014; Huebener et al. 2017, 6; Zee 2017; Chu 2019). Helga Tawil-Souri (2017, 384, 412) eloquently writes about this phenomenon in "Checkpoint Time," describing how Palestinians are forced to travel more slowly through checkpoints than others, and "are perceived and perceive themselves as stuck in a system that belongs to the past." The production of temporal hierarchies also clearly emerges in the aviation sector. For example, at international aviation conferences, operations managers in Nepal note that they feel isolated from a larger international community because they are seen as lagging behind in terms of technology and facilities. To some extent, the aviation personnel agree with this characterization of temporal inequality. Arun, an operations manager for a domestic airline, said that he felt extremely left out of the aviation world: "Nepalese aviation is still isolated. I know the fact that there are so many things that we are not able to meet up to, but we are not in the community you know, the aviation community. The international aviation community, where we can interact with people, share our problems.” A clear sense of frustration emerged as the global market demands unrealistic temporal expectations. Arun continued:

When I go to a program in global aviation, they're talking about 2030, 2040, 2050 — oh, my God. I'm there talking about 2018 - how to cope with the flights, how to delay the traffic, how to adjust the system. Oh, my God. Where am I? I just get out and get a coffee and I want a cigarette. That's the reality. That's my real reality. . . . We are training people to cope with 2018 only. ... The training design [here in Nepal] is how to deal with the problem, not the upcoming problem!

This stark inequality in the world of strategic aviation planning-where IATA predictions and strategic plans are at least two or three decades ahead, while CAAN is seen as simply putting out fires - means that Arun feels like Nepal has failed to even take part in the imagined futures of the global conversation in aviation. Thomas Yarrow (2017, 568), in his research on the Volta Resettlement dam project in Ghana, writes that the stalled project has created "a palpable sense of the failure of modernization to arrive, associated with an unstable and unresolved relationship between the actuality of existing circumstances and the imagined futures that continue to be projected from the unrealized plan.” But unlike in Yar- 
row's case, where there is a feeling of lament, and modernization is seen in the past tense, Nepali aviation personnel firmly believe they form a necessary part of the international aviation world — and by extension the flow of global capital — while timeframes are determined by international aviation regulators and protocol-defining agencies. Their views resemble what Karine Gagné and others refer to as "technocratic time" in recent work on Himalayan hydropower (Gagné 2019; Lord, Drew, and Gergan 2020). The standards and expectations of the aviation world are often described as disconnected from specific local conditions, which seems ironic in an industry that prides itself on movement across this divide. While global aviation is ordered by regulators, alliances, and manufacturers, regulation is perhaps too strong of a word for what happens in practice. For instance, ICAO has no enforcement authority. Multicarrier alliances (such as Star Alliance and OneWorld) mean that there is a semblance of international cooperation, even though each airline has to comply with national civil aviation requirements (Batteau 2001, 206). Yet the "softer" nature of ICAO still sets international standards and recommended practices in aviation that are understood as baseline practices for aviation authorities around the world, even if these recommendations are not feasible in parts of the global South. This notion of not being aligned with the temporal expectations of global aviation futures becomes evident in the self-deprecating jokes among aviation workers in Nepal, who perhaps again turn the blame and responsibility for inefficiency inward, and use the trope of future-forward global aviation to express frustration at the slowness of state-level infrastructural improvements. In a conversation with dispatchers from three different airlines, much laughter erupted after one man said that "the equipment we are using does not operate in the twenty-first century. I think we're using it for the twentieth century!” The international airport itself becomes a temporal symbol of what one operations manager called a "deep shame":

Even when I enter Nepal — with due respect to my country and my airport that we have-I feel like I'm still in the eighties, you know. Early eighties. I just look at the infrastructure, the airport, particularly when we come from outside. Like you have a flight from Heathrow or any good airport from Japan and you land in TIA [KTM], you look at the tower, you look at the facility, and you think, "I'm still in the early eighties." It feels the same! The irony or the fun part is that foreigners like that. Most of them have not seen such an environment in their country, or some have seen it maybe, but like thirty years ago or forty years before. 
Even the airport becomes a material symbol of the past. Foreign visitors emphasize this past for its retro or quaint nature, and landing at KTM — with its wooden engraved pillars and a single rickety escalator — becomes part of the entire passenger experience of flying to "traditional" Nepal. Ramesh the air traffic controller also recalled his shock at the cost-cutting measures of European and North American carriers at an airline industry event in Europe: "They are obsessed with . . . talking about how to save one cent! By making lighter aircraft, by direct routing, right? Because [Europeans] already have infrastructure, you have technology." He claimed that every international aviation event is targeted toward attracting business, but in Kathmandu, there is in fact no more space at the sole international airport to allow more airlines in. "Because we [did] not plan from twenty years ago." Although numerous other airports around the world are also approaching capacity (e.g., Schiphol airport in Amsterdam), the problem, according to Ramesh, is that the lack of long-term planning directives from Nepali ministries leads to a loss of business in Nepal. But perhaps feeling "behind" has more to do with the unequal values produced through the overlaps between the temporal and infrastructural hierarchies of global aviation, in other words, the structures of power exercised by dominant global aviation actors in both time and space. If everything does, and must, speed up to create seamless turnovers of capital, the models of success are high-capacity, economically successful international carriers and airport hubs like Emirates and Heathrow, where new air traffic-management technologies like Time Based Separation and Weather Based Separation have enabled more planes to fit in the sky by spacing aircraft evenly in fluctuating headwinds.

Many aviation workers stressed that the underlying factor in lagging behind the curve was not so much a lack of money for resources, since Chinese and Nepali contractors as well as the Asian Development Bank were investing significant sums in infrastructure expansion projects, including three new international airports and enhancements to air navigation systems (CAAN 2018). The lack of a stable political system, on the other hand, often came up in conversation. Over the past twenty years, huge ups and downs have characterized Nepali politics: a decade-long civil war, the royal family massacre in 2001, as well as various formations of congress, including members of Maoist and communist parties, and, as of 2019, a coalition government. One senior aircraft engineer said, "the problem I see is that here in Nepal, the government changes. One government doesn't last for the year. So there is a problem at the policy level, so that nobody can fix [anything]. So now we have a stable government; the Communists they hold the majority, so let's hope they run for five years and fingers crossed . . . because we want these 
things to be sorted, for us, for the aviation industry and for him as well [pointing to a young flight dispatcher looking for a new job]." Five-year policy implementation plans are common, but aviation workers become frustrated when they suspect that the government will change before the period is up. The policies and plans inevitably change as well, so while implementation is often unpredictable or delayed, new modes and arrays of political actors come to the fore (Nightingale et al. 2018, 853). However, even these new configurations have led to more than a bit of cynicism; as another engineer said, the "bureaucratic people . . . are saying "we are seeing the long term,' but the logic isn't working that way." As an example, he described an aircraft grounded because of a mechanical problem, for which it took the new management team a month and a half to simply decide to replace the engine. Again he mentioned feeling removed from the world and time of global aviation, seen as consistent, stable, and future-oriented.

These stories resemble what Dannah K. Dennis (2017, 104) has written about Kathmandu city roads, congested with traffic and disrepair: "Making one's way across the city is a daily experience of grinding, tedious, frustrating slowness. ... This physical feeling of being stuck, even while one may still be moving, mirrors the political inertia that has characterized Nepal for the last several decades." A representative from the Nepal branch of a large international airline also used the idea of global aviation time to vent his frustration with uncertainty in Nepali politics:

Ahmed: Over the past two years, I worked with four different ministers. Now we are waiting for the fifth. ... They cannot make any long-term plans, but aviation needs to be planned. When we go to a meeting with our [airline company] president, he said, "I am sure you should be thinking about 2053. I hope you've already started," they told me just like that. So aviation is an industry where you have to plan.

Me: So how do you plan for 2053 in Nepal?

[Everyone bursts out laughing.]

To be global is to be working on the future. If Nepal does not meet the temporal expectations of planning for 2053, it, and the various airlines based there, will get relegated to the bottom of the hierarchy in the world of global aviation. Here, in aviators' narratives of privileging the international over the domestic and of lagging behind global future standards, we learn something about "the time of the global." This time, marked by new technology and capital growth, is used to 
represent what aviators believe Nepal has not yet managed to achieve. Nepali aviation workers feel ostracized for all the reasons detailed: poor resources, shame at the airport from the 1980s, the lack of a stable government. Following a number of fatal aircraft crashes between 2010 and 2014, the ICAO and the EU blacklisted Nepali airlines. While the ICAO removed Nepal from the list of carriers with significant safety concerns in 2017, it remains on the EU air safety blacklist, hampering Nepal Airlines' idealistic future plans for long-haul direct flights to Europe (but not impeding renewed flights to labor migration destinations in Asia under headlines like "Winning Back the Skies"). These combined constraints continue to paint a picture of Nepal as a chaotic, crumbling, failed state, underscoring the image of the Nepali nation and its individual people as either incompetent and cutting corners or romanticized as quaint, living in a different timeframe. So while Nepali aviation staff work to make the infrastructure run in Kathmandu, a hub of migration to Southeast Asia and the Gulf States, the feeling of being isolated from international aviation conferences still dominated by Europe and North America demonstrates what Sarah Sharma (2014, 25; emphasis added) argues, that "keeping people in and out of time is a form of social control, one of the conditions of possibility for contemporary global capital.”

The feeling of being snubbed from the global aviation community has a knock-on effect, with tremendous stakes for both the safe maintenance of the local air infrastructure and the system as a whole. But being part of the world of global aviation requires careful training and staying on top of updated standard operating procedures, which of course takes time. Pilots and controllers need to log a certain number of hours of flight time to obtain varying levels of certification, and different airlines have different hourly expectations; this is what Marcel LaFlamme $(2018,98)$ has called an "economy of hours." In Nepal, because of its difficult terrain and history of air disasters, these hours are long-it takes 3,500 hours to become a captain, compared to the 1,500 hours minimum in many other parts of the world. As a result, aviation authorities and airlines in the global South often hire foreign engineers and pilots with the required flying hours to keep up with overcapacity and increasing flights, prioritizing efficiency and short-term solutions over the longer-term investment in training local aviation personnel. In Nepal and in many other parts of the global South, these international pilots earn significantly more than local pilots. When I asked a manager of a Southeast Asian carrier based in Nepal to tell me what is needed most in the aviation industry, he replied: 
Manpower. We need skilled, licensed people. The physical infrastructure will come; CAAN and the country will see to it eventually, but manpower is more difficult. It takes time to invest in people. People come back from training and studying, and the jobs are given to foreigners! Rather than foreigners, it needs to be Nepalese. Why pay a foreigner more than a Nepali? This is humiliation for Nepalese who don't get the same amount. These limitations are very unethical.

Hiring qualified foreign pilots at a higher salary is a quick fix to keep the infrastructure afloat in the short term. It is partly a response to a broader global pilot shortage, while at the same time shunning long-term investment in local people and reinforcing existing geopolitical binaries. And although the exact composition of these hierarchies is changing - Chinese pilots are now being hired in place of European pilots - these processes continue to "reduce time to a medium for the short-term generation of capital and the evaluation of worth" (Bear 2016, 489). The hiring of foreign pilots over local pilots for stopgap gain constitutes a temporal deferral that has wider repercussions, mirroring Ramesh's earlier lament that international departures seem to take priority over domestic ones. At these moments, infrastructural hierarchies and temporal hierarchies overlap through both forms of air pressure's effects, edging Nepali actors further out of the global discussion of aviation futures, though the idea of global aviation time is harnessed to express nationalistic frustration with the ways these structures are shaped: why shouldn't Nepali airlines and individuals be prioritized in these circumstances at the expense of other carriers?

As aviation personnel lament their international position, their criteria for judging the nation remains grounded in a neoliberal evaluation of time: its suitability for investment in the future or its ability to plan for continuity. The lack of cutting-edge aviation technologies in Nepal is often attributed to governmental unpredictability, unstable regimes, and a lack of political continuity. Even so, these situations also demand more time to resolve. This increases the pressure on aviation personnel, who must reconcile the time of the nation and its requirements for internal transformation with the speed and tempo necessary to harmonize the global flows that intersect in its space. The effects resonate in both directions. Aviation workers in Nepal must have more time to keep aircraft in the air, in part because they lack the space and material resources to maintain this efficiency domestically. And yet, their successful efforts enable international airlines to valorize capital directed toward the maintenance of air infrastructure systems elsewhere, 
in other parts of the world. When investment is made in infrastructural projects in Nepal itself — construction for a second international airport is well underwayworkers know that the labor necessary to sustain it will need to be performed in the future. Aviators are participating in and enabling an in-between kind of temporality, one not entirely about the backwardness of the nation, but one in which their time and labor become necessary to build a broader anticipatory future. Pointing out these deferrals of time is both a source of vexation and a justification for working toward greater control over time and space in the years to come.

\section{WEATHER PERMITTING: In the Time of the Global}

In contemporary discourses on the practices and politics of aviation infrastructure, uneven geographical understandings are often framed in terms of time. Focusing on the ways that global time is both structured and used bring us to a more multidimensional understanding of globalization, a counterpoint to the more spatial emphases of critical logistics and 'scapes (Appadurai 1990). The two sets of experiences of air pressure outlined in this essay are intertwined in that they are both subject to capitalist speedups that play out distinctively in the context of Nepal and its place in what Michael Herzfeld (2004) calls a "global hierarchy of value," due to international standards that do not work as well in the specific local context. International aviation regulators set the plannable future at the year 2050, and are not always fully cognizant of how such temporal expectations play out on the ground (or in the air, for that matter) in places other than the global North. In the aviation industry, the seamlessness of infrastructure capitalism "should be" a global system and therefore uninterrupted. But interruption, bottlenecks, and choke points (Cons 2018) can also push the domestic ahead of the international, keeping traffic - and capital_flowing in unanticipated ways. Aviators in Nepal highlight their experiences of the pressure of the time of the global_-providing a kind of diagnosis of the overall unequal system of aviation infrastructure - while also contributing to these inequalities in ways not nearly as visible as a new airport might be, through the lens of the time of the nation.

At one mountain airport in Nepal, I sat watching the small but sturdy turboprop "twin otter" planes from Kathmandu soar in, one after another. The few parking bays were full; while the cabin crew and operations teams attempted to quickly deplane the arriving passengers and board a queue of ten to fourteen departing passengers. The next plane to land was barely visible in the mist, hovering over the mountains and slowly beginning to descend into the valley. With a sudden rush of sound and air, it roared along the mountainside runway and shuddered to 
a quick stop - the STOL (short takeoff, short landing) runway is only several hundred meters long. The early afternoon weather was moving in, and there seemed to be no parking space for more aircraft. The passengers began disembarking on the runway itself. On the digital display in the tower, the wind read eight knots; if it went above ten, the airport would close. The same was true for visibility under five kilometers. Later, several pilots came up for some frothy coffee and a quick break. They said to us, "It was bad out there. They're making us fly."

One of the controllers told me that aviation personnel felt like they were just keeping their heads above water, trying to do their best to keep air traffic flowing as smoothly as possible while working under a plethora of circumstances beyond their control, including nonhuman factors such as hailstorms and mountain clouds. But congestion and disruption can also prove productive in curious ways (Carse, Cons, and Middleton 2018; Carse et al. 2020). Veteran Himalayan pilots reported that climate change has indeed altered their experiences of flying. They said that the weather above the mountains had become more volatile and unpredictable over the past few decades, with more turbulence, leading to more delays. "There are two kinds of weather," remarked a pilot who regularly flies to remote locations in Nepal. One type is "complete weather," serious storms for which flights must be cancelled. The other kind of weather, according to him, is weather that you can do something about, given the right equipment. This is when it's dark or foggy, "but you are not able to fly because of not having the technology. That is where it hits you. That is when passengers get irritated, we as employees get irritated, the [aviation] authority - they are not doing anything. We could have flown in this situation!" Yet in many aviation circles, being able to fly manually in unpredictable weather above inaccessible mountains is seen as an asset, since aircraft have become increasingly automated. The (re)valorization and (re)strengthening of manual or hand-flying skills is thus a key recommendation in critiques of the reliance on automation in flight (Haslbeck and Hoermann 2016). In the aftermath of several accidents such as the Boeing 737 MAX crashes in Ethiopia and Indonesia, concerns have emerged about young pilots being "lulled into a sense of security" by automation; the U.S.-based Federal Aviation Administration has even suggested that crew now turn off autopilot on clear days to hone their hand-flying skills (Mark 2017; Nicas and Wichter 2019). Aviation enthusiasts on social media forums around the world discuss the latest flight simulator programs that reproduce tough airport landings and takeoffs in Bhutan and Nepal, considered the highest level of difficulty, while Nepali pilots laugh and say that they wish they had had access to these programs before flying for the first time to these airports. 
Adriana Petryna $(2018,588)$ has noted that both firefighters and seafarers have a "continual capacity for recalibration" when faced with changing environmental conditions, and Ashley Carse $(2020,4)$ has also noted that the manual "feel" for piloting container ships has in fact increased in importance for transport authorities as vessels grow in size and sea levels continue to rise. Like pilots who fly to high-altitude airports in inclement weather, they must manually adjust for change to avoid disaster. This understanding of the nuances and fluctuations of the skies — of clouds, mist, storms, and turbulence-flips the temporal-infrastructural hierarchy on its head. Here, Nepali civil aviators are perceived by other industry professionals as cutting edge because they possess the increasingly rare skills to manually maneuver aircraft in emergency situations that automation such as autopilots are sometimes unable to fully detect or solve.

With increasingly volatile, turbulent skies, caused in part by emissions from the aviation industry itself, those able to deal with such weather unaided by technology are seen as ahead of the game. As we have seen, the time of the global is both controlling and useful; it is oppressive but can be harnessed. Here, the use of analog technology is not seen as some sort of "turning back the clock" to early twentieth-century civil aviation, but as a unique asset specific to the experiences of being an aviator in Nepal — it is what is needed to move forward and anticipate the future of climate uncertainty. The question, of course, is who will use these skills, for what purpose, and to what extent they will be appropriated for the survival of capital. This, then, is how the overlaps between infrastructural and temporal hierarchies point to unpredictable new futures, and this very uncertainty is what generates both frustration and hope.

\begin{abstract}
While the aviation industry is dominated by narratives of smooth, unending growth and future planning, in practice it is profoundly striated and asymmetrical. Through an ethnographic study of how air traffic controllers, pilots, and operations staff in Nepal experience "air pressure," this article demonstrates how understandings of the uneven geography of aviation infrastructure are framed in terms of time. Nepali airports are often perceived as "lagging behind" or "quaint" in comparison to other airports around the world, and air traffic congestion in Nepal can create bottlenecks that in turn have massive implications for the wider system. Yet some kinds of disruption - such as unpredictable weather - reconfigure familiar hierarchies, bringing the value of Nepali aviators' knowledge of how to manage difficult skies to the forefront of aviation futures. Aviation personnel highlight and expose severe inequalities in global aviation infrastructure systems while also contributing to them in ways that
\end{abstract}


reveal specific ideas about the future of the nation. Unravelling these "tangles of temporalities" may provide a better understanding of how global temporal regimes are harnessed so as to shape lives. [aviation; temporality; infrastructure; mobility; futures; Nepal]

\section{सारांश}

उड्डयन उद्योग सहज तथा नरिन्तर वृद्धा हुने र भावी योजना बनरिहने क्षेत्र हो भन्ने भाष्य हावी छ, तर व्यवहारमा यो अत्यन्त खण्डति र वषिम छ। नेपालका हवाई ट्राफकि नयिन्त्रक, वमिान चालक, र हवाई सेवा सज्चालन कर्मचारीहरूले कसरी "हवाई चाप" लाई अनुभव गर्छ् भन्ने वषियको एथ्नोग्राफकि अध्ययनको आधारमा यो लेखले उड्डयन पूर्वाधारको असमान धरातललाई कसरी कालकि ढाँचामा बुझ्ने गरन्छ्छ भन्ने देखाउन खोजेको छ। वश्विका अरू वमिनस्थलहरूको तुलनामा नेपालका वमिनस्थलहर “पछिडिएका" र “वचित्रिका" मानएि पना, नेपालमा हवाई ट्राफकिको घुइँचोले वभिन्न अवरोधहरू सर्जिना गर्न सक्छन्, जसले सड्गिगो प्रणालीमा बृहत् प्रभाव पार्न सक्ने कुराको सड्केत गर्छ। अप्रत्याशति मौसम परविर्तन जस्ता केही अवरोधले उड्डयन उद्योगमा वद्यिमान श्रेणीयताहरू (हायरार्की) को पुनर्वन्यिस गरदिन्छिन्, जसले नेपाली उड्डयन कर्मचारीहरूले वषिम परस्थितिमिा गर्दै आएको हवाई ट्राफकि व्यवस्थापनको ज्ञानको महत्त्वलाई उड्डयन भवष्यिय बजारको अग्रपड्तमि ल्याइदन्छि। उड्डयन कर्मचारीहरूले वैश्वकि उड्डयन पूर्वाधार प्रणालीहरमा रहेका गम्भीर असमानताहरू झल्काउनका साथै ती असमानताहरू सर्जिजा गर्नमा पना योगदान गर्छन्, र राष्ट्रको भवष्यि बारेका नश्चिचि वचिराहरूलाई उद्घाटति गर्छन्। यी “कालकिताहरूका गुजुल्टा" को फुकाइले कसरी जनजीवनलाई प्रभाव पार्न वैश्वकि कालकि व्यवस्थालाई उपयोगमा ल्याइन्छ् भन्ने बारे अझ राम्ररी बुझ्न मद्दत गर्न सक्छ । [उड्डयन; कालकिता; पूर्वाधार; गतशिलता; भवष्यि; नेपाल]

\section{NOTES}

Acknowledgments My utmost appreciation goes to the members of the aviation community in Nepal who took the time to chat with me, particularly the Aviation Nepal team; I cannot thank you enough. Chris Nelson and three anonymous reviewers facilitated one of the most supportive peer review procedures I have ever experienced. Mahesh Raj Maharjan, Anisa Bhutia, and Sneha Moktan provided invaluable assistance with the translation of the abstract. Finally, I would like to acknowledge all the thoughtful comments and suggestions from Marcel LaFlamme and Jason Cons, as well as from friends and colleagues at the Asian Borderlands Conference in Bishkek, the UBC Himalaya Program Lecture series, and the Moving Matters Program Group at the University of Amsterdam.

1. The research and writing of this article spanned 2018-2020, prior to the emergence of the COVID-19 pandemic. At that time, the aviation industry was in the midst of unprecedented growth. The severe cuts to the industry during the pandemic could significantly alter these numbers and predictions.

2. I would like to thank Reviewer 1 for their elegant, spot-on phrases such as this one.

3. In March 2019, the runway underwent its first major repair since its construction in 1957, resulting in a number of reroutings and limited operation hours. 


\section{REFERENCES}

Adam, Barbara

1998 Timescapes of Modernity: The Environment and Invisible Hazards. London: Routledge.

Adey, Peter

2010 Aerial Life: Spaces, Mobilities, Affects. Malden, Mass.: Wiley-Blackwell.

Anand, Nikhil

2011 "Pressure: The PoliTechnics of Water Supply in Mumbai." Cultural Anthropology 26, no. 4: 542-64. https://doi.org/10.1111/j.1548-1360.2011.01111.x.

2017 Hydraulic City: Water and the Infrastructures of Citizenship in Mumbai. Durham, N.C.: Duke University Press.

Anand, Nikhil, Akhil Gupta, and Hannah Appel, eds.

2018 The Promise of Infrastructure. Durham, N.C.: Duke University Press.

Appadurai, Arjun

1990 "Disjuncture and Difference in the Global Cultural Economy." Theory, Culture and Society 7, no. 2-3: 295-310. https://doi.org/10.1177/026327690007002017.

Ballestero, Andrea

2019 A Future History of Water. Durham, N.C.: Duke University Press.

Batteau, Allen W.

2001 "The Anthropology of Aviation and Flight Safety." Human Organization 60, no. 3 : 201-11. https://doi.org/10.17730/humo.60.3.3q5m5dylr01p1qa4.

Bear, Laura

2016 “Time as Technique." Annual Review of Anthropology 45: 487-502. https://doi. org/10.1146/annurev-anthro-102313-030159.

Berlant, Lauren

2016 "The Commons: Infrastructures for Troubling Times." Environment and Planning D: Society and Space 34, no. 3: 393-419. https://doi.org/10.1177\% 2F0263775816645989.

Bhimull, Chandra D.

2017 Empire in the Air: Airline Travel and the African Diaspora. New York: NYU Press.

Billé, Franck, ed.

2018 "Speaking Volumes." Theorizing the Contemporary, Fieldsights, June 27. https:// culanth.org/fieldsights/series/speaking-volumes.

Birtchnell, Thomas, and Monika Büscher

2011 “Stranded: An Eruption of Disruption.” Mobilities 6, no. 1: 1-9. https://doi.org/10 $.1080 / 17450101.2011 .532648$.

Bowker, Geoffrey C.

2015 “Temporality." Theorizing the Contemporary, Fieldsights, September 24. https:// culanth.org/fieldsights/temporality.

Budd, Lucy, and Peter Adey

2009 "The Software-Simulated Airworld: Anticipatory Code and Affective Aeromobilities." Environment and Planning A: Economy and Space 41, no. 6: 1366-85. https://doi.org/10.1068/a41249.

CAAN (Civil Aviation Authority of Nepal)

20172017 CAAN Souvenir. http://dspace-caan.healthnet.org.np:8080/caan/handle/ $123456789 / 255$.

2018 Civil Aviation Annual Report 2018. Kathmandu: CAAN.

Carse, Ashley

2020 "The Feel of 13,000 Containers: How Pilots Learn to Navigate Changing Logistical Environments.” Ethnos. Published ahead of print, May 14, 2020. https://doi.org/ 10.1080/00141844.2019.1697337.

Carse, Ashley, Townsend Middleton, Jason Cons, Jatin Dua, Gabriela Valdivia, and Elizabeth Cullen Dunn

2020 "Chokepoints: Anthropologies of the Constricted Contemporary." Published ahead of print, May 15, 2020. Ethnos. https://doi.org/10.1080/00141844.2019.169 6862 . 
Carse, Ashley, Jason Cons, and Townsend Middleton, eds.

2018 "Chokepoints." Special issue, Limn 10. https://limn.it/issues/chokepoints/.

Chu, Julie Y.

2019 "Risky Work, Fateful Play: Chinese Customs Inspectors and the Compossibility of Fortune." Ethnos 84, no. 2: 201-22. https://doi.org/10.1080/00141844.2017.1394 348.

Cons, Jason

2018 “The Times of Chokepoints." Limn 10. https://limn.it/articles/the-times-ofchokepoints/.

2020 "Delta Temporalities: Choked and Tangled Futures in the Sundarbans." Ethnos. Published ahead of print, May 14, 2020. https://doi.org/10.1080/00141844.2019.

Cowen, Deborah 1697334.

2014 The Deadly Life of Logistics: Mapping Violence in Global Trade. Minneapolis: University of Minnesota Press.

Cwerner, Saulo, Sven Kesselring, and John Urry

2009 Aeromobilities. London: Routledge.

Dennis, Dannah K.

2017 "On the Road to Nowhere: Stalled Politics and Urban Infrastructure in Kathmandu." HIMALAYA 37, no. 1: 98-106. https://digitalcommons.macalester. edu/himalaya/vol37/iss1/14.

Easterling, Keller

2014 Extrastatecraft: The Power of Infrastructure Space. London: Verso.

Elden, Stuart

2013 "Secure the Volume: Vertical Geopolitics and the Depth of Power." Political Geography 34: 35-51. http://dx.doi.org/10.1016/j.polgeo.2012.12.009.

Estival, Dominique, Candace Farris, and Brett Molesworth

2016 Aviation English: A Lingua Franca for Pilots and Air Traffic Controllers. London: Routledge.

Fabian, Johannes

2014 Time and the Other: How Anthropology Makes Its Object. New York: Columbia University Press. Originally published in 1983.

Frederiksen, Martin Demant, and Anne Line Dalsgård

2014 "Introduction: Time Objectified." In Ethnographies of Youth and Temporality: Time Objectified, edited by Anne Line Dalsgård, Martin Demant Frederiksen, Susanne Højlund, and Lotte Meinert, 1-21. Philadelphia: Temple University Press.

Gagné, Karine

2019 "Waiting for the Flood: Technocratic Time and Impending Disaster in the Himalayas.” Disasters 43, no. 4: 840-66. https://doi.org/10.1111/disa.12379.

Gambino, Evelina

2018 "The New Silk Road and Logistical Geopolitics." Society and Space Magazine, March 27. http://societyandspace.org/2018/03/27/the-new-silk-road-and-logisticalgeopolitics/.

Golf, Tango

2017 "Blooming Aviation Urges for Airport Expansion in Nepal." Aviation Nepal, May 26. http://www.aviationnepal.com/blooming-aviation-urges-for-airportexpansion-in-nepal/.

Graham, Stephen, and Nigel Thrift

2007 "Out of Order: Understanding Repair and Maintenance." Theory, Culture and Society 24, no. 3: 1-25. https://doi.org/10.1177\%2F0263276407075954.

Gupta, Akhil

2015 "An Anthropology of Electricity from the Global South." Cultural Anthropology 30, no. 4: 555-68. https://doi.org/10.14506/ca30.4.04.

Guyer, Jane I.

2016 Legacies, Logics, Logistics: Essays in the Anthropology of the Platform Economy. Chicago: University of Chicago Press. 
Hartog, François

2015 Regimes of Historicity: Presentism and Experiences of Time. Translated by Saskia Brown. New York: Columbia University Press.

Harvey, David

1989 The Condition of Postmodernity. Oxford: Blackwell.

Haslbeck, Andreas, and Hans-Jeurgen Hoermann

2016 "Flying the Needles: Flight Deck Automation Erodes Fine-Motor Flying Skills among Airline Pilots.” Human Factors 58, no. 4: 533-45. https://doi.org/ $10.1177 / 0018720816640394$.

Herzfeld, Michael

2004 The Body Impolitic: Artisans and Artifice in the Global Hierarchy of Value. Chicago: University of Chicago Press.

Hetherington, Kregg

2017 "Surveying the Future Perfect: Anthropology, Development and the Promise of Infrastructure." In Infrastructures and Social Complexity: A Companion, edited by Penelope Harvey, Casper Bruun Jensen, and Atsuro Morita, 40-50. London: Routledge.

Hetherington, Kregg, ed.

2019 Infrastructure, Environment, and Life in the Anthropocene. Durham, N.C.: Duke University Press.

Huebener, Paul, Susie O’Brien, Tony Porter, Liam Stockdale, and Yanqiu Rachel Zhou, eds.

2017 Time, Globalization and Human Experience: Interdisciplinary Explorations. Abingdon: Routledge.

IATA (International Air Transport Association)

2018 Future of the Airline Industry 2035. https://www.iata.org/policy/Documents/iatafuture-airline-industry.pdf.

ICAO (International Civil Aviation Organization)

2018 Annual Report of the Council 2018. https://www.icao.int/annual-report-2018/.

Ingold, Tim

2010 "Footprints through the Weather-World: Walking, Breathing, Knowing." Journal of the Royal Anthropological Institute 16, no. S1: S121-S139. https://doi.org/10.1111/ j.1467-9655.2010.01613.x.

Joniak-Lüthi, Agnieszka

2019 "Introduction: Infrastructure as an Asynchronic Timescape." Roadsides 001. https://roadsides.net/joniak-001/.

Kim, Hyejeong

2018 "What Constitutes Professional Communication in Aviation: Is Language Proficiency Enough for Testing Purposes?” Language Testing 35, no. 3: 403-26. https://doi.org/10.1177/0265532218758127.

Kitchin, Rob, and Martin Dodge

2014 Code/Space: Software and Everyday Life. Cambridge, Mass.: MIT Press.

LaFlamme, Marcel

2018 "Remaking the Pilot: Unmanned Aviation and the Transformation of Work in Postagrarain North Dakota.” PhD diss., Rice University.

Lin, Weiqiang

2014 "The Politics of Flying: Aeromobile Frictions in a Mobile City." Journal of Transport Geography 38: 92-99. https://doi.org/10.1016/j.jtrangeo.2014.06.002.

2018 "Catering for Flight: Rethinking Aeromobility as Logistics." Environment and Planning D: Society and Space 36, no. 4: 683-700. https://doi.org/10.1177\% 2F0263775817697977.

Lin, Weiqiang, and Qi Ai

2020 “'Aerial Silk Roads': Airport Infrastructures in China's Belt and Road Initiative." Development and Change 51, no. 4: 1123-45. https://doi.org/10.1111/dech.12606. 
Lord, Austin, Gina Drew, and Mabel Denzin Gergan

2020 "Timescapes of Himalayan Hydropower: Promises, Project Life Cycles, and Precarities." WIREs Water 7, no. 6. https://doi.org/10.1002/wat2.1469.

Mark, Rob

2017 “FAA: Manual Flying Skills Still Lacking.” Flying, May 16. https://www.flyingmag. com/faa-manual-flying-skills-still-lacking/.

Martin, Daryl

2011 "Eyjafjallajökull 4'33": A Stillness in Three Parts." Mobilities 6, no. 1: 85-94. https://doi.org/10.1080/17450101.2011.532656.

Nicas, Jack, and Zach Wichter

2019 “A Worry for Some Pilots: Their Hands-On Flying Skills Are Lacking.” New York Times, March 14. https://www.nytimes.com/2019/03/14/business/automatedplanes.html.

Nightingale, Andrea J., Anil Bhattarai, Hemant R. Ojha, Tulasi Sharan Sigdel, and Katharine

N. Rankin

2018 "Fragmented Public Authority and State Un/making in the 'New' Republic of Nepal.” Modern Asian Studies 52, no. 3: 849-82. https://doi.org/10.1017/ S0026749X16000500.

Peters, Peter

2009 “Airborne on Time." In Aeromobilities, edited by Saulo Cwerner, Sven Kesselring, and John Urry, 159-76. London: Routledge.

Petryna, Adriana

2018 "Wildfires at the Edges of Science: Horizoning Work amid Runaway Change." Sharma, Sarah

Cultural Anthropology 33, no. 4: 570-95. https://doi.org/10.14506/ca33.4.06.

2014 In the Meantime: Temporality and Cultural Politics. Durham, N.C.: Duke University Press.

2016 "Speed Traps and the Temporal: Of Taxis, Truck Stops, and Task Rabbits." In The Sociology of Speed: Digital, Organizational, and Social Temporalities, edited by Judy Wajcman and Nigel Dodd, 131-51. Oxford: Oxford University Press.

Sheller, Mimi

2010 "Air Mobilities on the U.S.-Caribbean Border: Open Skies and Closed Gates." Communication Review 13, no. 4: 269-88. https://doi.org/10.1080/10714421.2010. 525469 .

Sheller, Mimi, and John Urry

2006 "The New Mobilities Paradigm." Environment and Planning A: Economy and Space 38, no. 2: 207-26. https://doi.org/10.1068/a37268.

Simone, AbdouMaliq

2004 "People as Infrastructure: Intersecting Fragments in Johannesburg." Public Culture 16, no. 3: 407-29. https://doi.org/10.1215/08992363-16-3-407.

Tawil-Souri, Helga

2017 “Checkpoint Time.” Qui Parle 26, no. 2: 383-422. https://doi.org/10.1215/ 10418385-4208442.

Thapa, Deepak, ed.

2019 The Politics of Change: Reflections on Contemporary Nepal. Kathmandu: Vajra Books.

Virilio, Paul

1986 Speed and Politics. Los Angeles: Semiotext(e).

Yarrow, Thomas

2017 "Remains of the Future: Rethinking the Space and Time of Ruination through the Volta Resettlement Project, Ghana." Cultural Anthropology 32, no. 4: 566-91.

Zee, Jerry C. https://doi.org/10.14506/ca32.4.06.

2017 "Holding Patterns: Sand and Political Time at China's Desert Shores." Cultural Anthropology 32, no. 2: 215-41. https://doi.org/10.14506/ca32.2.06. 